\title{
ETNOBOTANI TANAMAN OBAT DI KECAMATAN NANGAPANDA KABUPATEN ENDE NUSA TENGGARA TIMUR
}

\author{
(Ethnobotanical Study of Medicinal Plants Used in Nangapanda, Ende, \\ Nusa Tenggara Timur)
}

\author{
Maria Tensiana Tima, Sri Wahyuni \& Murdaningsih'
}

\begin{abstract}
This study aims to obtain information about community knowledge and types of medicinal plants used by the people of the Nangapanda District, East Nusa Tenggara Province. This research was conducted in three villages in the Nangapanda subdistrict namely West Ondorea Village, Timba Zi'a and Uzu Zozo Village. Data collection was carried out by interviewing and distributing questionnaires to gather information about the use of medicinal plants by the community and track that aims to equate the results of interviews and questionnaires with the actual situation at the study site. The results showed that $73 \%$ of people use medicinal plants for preventive and healing activities and there are 54 types of medicinal plants used.
\end{abstract}

Keywords : Ethnobotany, medicinal plants, Nangapanda

\begin{abstract}
ABSTRAK
Pengetahuan tentang tanaman obat diperoleh masyarakat secara turun temurun dari generasi sebelumnya. Namun, dengan perkembangan zaman, pengetahuan tersebut mulai tidak diketahui oleh generasi saat ini. Penelitian ini bertujuan untuk memperoleh informasi tentang pengetahuan masyarakat dan jenis tanaman obat yang digunakan oleh masyarakat Kecamatan Nangapanda, Kabupaten Ende, Nusa Tenggara Timur. Penelitian ini dilaksanakan di tiga desa di kecamatan Nagapanda, yaitu Desa Ondorea Barat, Timba Zi'a dan Uzu Zozo. Pengumpulan data dilakukan dengan metode wawancara dan penyebaran angket untuk menggali informasi tentang pemanfaatan tanaman obat oleh masyarakat serta tracking yang bertujuan untuk mencocokkan hasil wawancara dan angket dengan keadaan sebenarnya di lapangan. Hasil penelitian menunjukkan terdapat $73 \%$ masyarakat yang menggunakan tanaman obat untuk kegiatan preventif maupun penyembuhan penyakit dan terdapat 54 jenis tanaman yang digunakan.
\end{abstract}

Kata Kunci : Etnobotani, tanaman obat, Nangapanda

Author Institution $\quad$ : $\quad$ 'Fakultas Pertanian Universitas Flores-Jalan Sam Ratulangi Kelurahan Paupire, Kecamatan Ende Tengah, Kabupaten Ende Nusa Tenggara Timur

Koresponding Author : Tel.082144564259; Email: 'tencyello@gmail.com

Articel History $\quad$ : Received 18 November 2019; received in revised from 18 February 2020; accepted 8 April 2020; Available online since 30 April 2020

http://doi.org// 0.20886/jpkf.2020.4.I.23-38

\section{PENDAHULUAN}

Jenis tanaman tingkat tinggi yang hidup di Indonesia sebanyak 35.000 jenis dan 3.500 jenis diantaranya adalah tanaman obat (Suryanto \& Djoni, 20I3). Hal ini menunjukkan bahwa Indonesia memiliki

potensi yang sangat besar untuk mengembangkan tanaman obat dengan kualitas yang setara dengan obat konvensional. Bahkan saat ini industri tanaman herbal sudah mulai berkembang 
pesat akibat adanya kompensasi bahwa pengobatan herbal memberikan dampak negatif yang sangat kecil jika dibandingkan dengan peggunaan obat konvensional (Sari, 2006).

Tumbuhan obat merupakan tumbuhan berkhasiat obat yang dapat menghilangkan rasa sakit, meningkatkan daya tahan tubuh, membunuh bibit penyakit dan memperbaiki organ yang rusak seperti ginjal, jantung dan paru-paru (Darsini, 20l3). Tumbuhan obat sangat erat kaitannya dengan pengobatan tradisional, karena sebagian besar pendayagunaannya belum didasarkan pada pengujian klinis laboratorium, melainkan lebih berdasarkan pada pengalaman penggunaan. Pengetahuan tentang tanaman obat diperoleh dari pengalaman dan keterampilan yang secara turun temurun telah diwariskan dari satu generasi ke generasi berikutnya (Sari, 2006).

Sejak jaman dahulu masyarakat Indonesia telah mengenal pemanfaatan tanaman herbal secara baik sebagai upaya dalam menjaga stamina hingga mengobati masalah kesehatan. Pemanfaatan tanaman herbal dapat digunakan secara tunggal maupun diracik bersama-sama dengan beberapa jenis tanaman herbal lainnya. Pengetahuan-pengetahuan tersebut diajarkan secara turun-temurun, bahkan menjadi ciri khas dari suatu daerah seperti jamu kunir asam dan beras kencur yang melekat pada masyarakat Jawa, minyak tawon khas Sulawesi Selatan, minyak pakoles khas Bali dan sebagainya.

Etnobotani merupakan bidang ilmu yang mempelajari hubungan antara manusia (etnik/kelompok masyarakat) dan interaksinya dengan tumbuhan. Interaksi pada setiap daerah memiliki karakteristik tersendiri dan sangat bergantung pada karakteristik wilayah serta potensi kekayaan tumbuhan yang ada. Menurut Nofiani (2008) tanaman memiliki dua jenis senyawa metabolit yaitu metabolit primer dan metabolit sekunder. Metabolit primer digunakan dalam pertumbuhan dan dibentuk dalam jumlah terbatas, sedangkan metabolit sekunder pembentukannya diatur oleh nutrisi, penurunan kecepatan pertumbuhan, feedback kontrol, inaktivasi enzim dan induksi enzim.

Kabupaten Ende merupakan salah satu kabupaten yang memiliki potensi keragamanan hayati tanaman obat yang khas akibat kondisi topografi yang berbeda dari daerah-daerah lain di Indonesia. Salah satu daerah di Kabupaten Ende yang masih teguh memegang tradisi budaya khususnya tentang pengobatan adalah Kecamatan Nangapanda yaitu pada Desa Ondorea Barat, Timba Zi'a dan Uzu Zozo. Tanaman-tanaman obat tersebut banyak digunakan oleh Ata bhisa (dukun kampung) dalam kegiatan pengobatan maupun tindakan preventif bagi masyarakat setempat. Hasil wawancara dari beberapa masyarakat di Kecamatan Nangapanda diketahui beberapa tanaman seperti kembo (Morinda citrifolia L.), daunnya untuk mengobati penyakit panas dan air rebusan buahnya untuk mengobati diabetes, iza (Jatrhopa curcas L.) rebusan kulit batangnya untuk mengobati hipertensi dan daunnya untuk penurun panas, muku (Musa paradisiaca) rebusan daun muda untuk menurunkan hipertensi. Tanaman mengkudu sebagai obat telah banyak diteliti oleh para peneliti antara lain oleh Sari, (2015) yang mengatakan bahwa mengkudu dapat menurunkan tekanan darah. Mengkudu aman dikonsumsi karena digolongkan dalam zat yang tidak toksik (Santosa, 2015). Wang et al. (2002) juga memiliki efek reparasi, peremajaan sel, efek antioksidan dan anti 
jamur, dan mengandung xeronine (mengatasi infeksi jamur dan meningkatkan imunitas tubuh). Sementara itu, penelitian tentang tanaman pisang juga telah dilakukan oleh Wibowo \& Prasetyaningrum (2015) yaitu pemanfaatan ekstrak batang tanaman pisang sebagai obat anti acne.

Seiring perjalanan waktu, pengetahuanpengetahuan tersebut mulai tidak diketahui oleh generasi sekarang bahkan penggunaan tanaman obat untuk tindakan preventif maupun kuratif sekarang sudah mulai ditinggalkan dengan berbagai alasan seperti kurang praktis dalam penyajiannya, sulit mendapatkan bahan/tanaman obatnya, efek penyembuhan membutuhkan waktu dan banyaknya obat konvensional yang beredar di masyarakat dengan harga yang lebih murah. Namun demikian, disisi lain banyak masyarakat kembali ke pengobatan alternatif apabila dirasa penanganan medis kurang memuaskan atau dapat menyandingkan antara pengobatan medis dan pengobatan alternatif termasuk dengan memanfaatkan tanaman herbal.

Oleh karena itu informasi tentang pengetahuan masyarakat dan jenis tanaman obat yang digunakan oleh masyarakat khusunya di Kecamatan Nangapanda, sangat diperlukan.

\section{METODE PENELITIAN}

Penelitian ini merupakan penelitian deskriptif eksploratif.

\section{A. Lokasi dan Waktu Penelitian}

Penelitian dilaksanakan di tiga desa yang terletak di Kecamatan Nangapanda Kabupaten Ende, Propinsi Nusa Tenggara Timur yaitu Desa Ondorea Barat, Desa Timba Zi'a dan Desa Uzu Zozo. Pemilihan lokasi tersebut dilakukan karena ketiga desa tersebut dihuni oleh masyarakat yang biasa memanfaatkan obat-obatan tradisional yang ada di sekitar mereka untuk keperluan penyembuhan penyakit serta masih mempertahankan kearifan lokal atau nilai-nilai budaya yang menjadi ciri khas masyarakatnya.

\section{B. Teknik Pengumpulan Data}

Pengumpulan data dilakukan dengan metode wawancara, angket dan tracking. Wawancara dan angket dilakukan terhadap masyarakat dengan berbagai tingkat usia, yaitu anak-anak, remaja, orang dewasa hingga para tua adat, dengan tujuan untuk mengetahui apakah pengetahuan tentang tanaman obatobatan diwariskan dari generasi ke generasi yang mendiami ketiga desa tersebut. Angket ini memuat nama, usia, jenis kelamin, pekerjaan dan pendidikan. Tracking dilakukan untuk mencocokkan hasil wawancara dan angket dengan keadaan yang sebenarnya di lapangan. Tumbuhan yang ditemukan kemudian didokumentasikan dengan kamera digital. Data tanaman obat yang diperoleh kemudian diidentifikasi berdasarkan nama lokal, nama ilmiah, famili, bagian tanaman yang digunakan, dan cara pengolahannya.

\section{Analisis Data}

Pada penelitian ini, pengolahan data dilakukan secara deskriptif. Data yang diolah meliputi data pokok yang memuat jenis tanaman obat, bagian tanaman yang digunakan, dan cara pengolahannya serta data pendukung yang memuat nama, usia, jenis kelamin, pekerjaan dan pendidikan responden. Estimasi kegunaan suatu jenis (used value) untuk tanaman obat dilakukan dengan menggunakan rumus Philips dan Gentry (1993) (Hoffman \& Gallaer, 2007) :

$$
U V_{\text {is }}=\frac{\sum U_{\text {is }}}{n_{\text {is }}}
$$


Keterangan:

(Remarks):

$\mathrm{UV}_{\text {is }} \quad$ : nilai kegunaan (manfaat) suatu jenis tertentu (i) yang disampaikan oleh informan (s)

$\Sigma \bigcup_{\text {is }} \quad$ : jumlah seluruh kegunaan jenis (i) yang dijelaskan setiap kali bertanya

$\mathrm{n}_{\text {is }} \quad$ : jumlah total informan yang diwawancarai untuk nilai guna jenis

Dengan kriteria sebagai berikut: Jika $0=$ $\mathrm{UV}_{\text {is }}=$ species not used; Jika $0<\mathrm{V}_{\text {is }}<$; jika $3=$ species less important; not priority species; jika 3 $\leq U V_{\text {is }} \leq 6$ = species important; priority species dan jika $6<U V_{\text {is }} \leq 9=$ species very important.

\section{HASIL DAN PEMBAHASAN}

\section{A. Karakteristik Responden}

Responden yang digunakan dalam penelitian ini berjumlah 135 orang dan tersebar di tiga wilayah yaitu di Desa

\section{Usia}

Variasi usia responden yaitu dari usia di bawah 20 tahun hingga di atas 60 tahun. Data responden berdasarkan karakteristik usia dapat dilihat pada Gambar I.

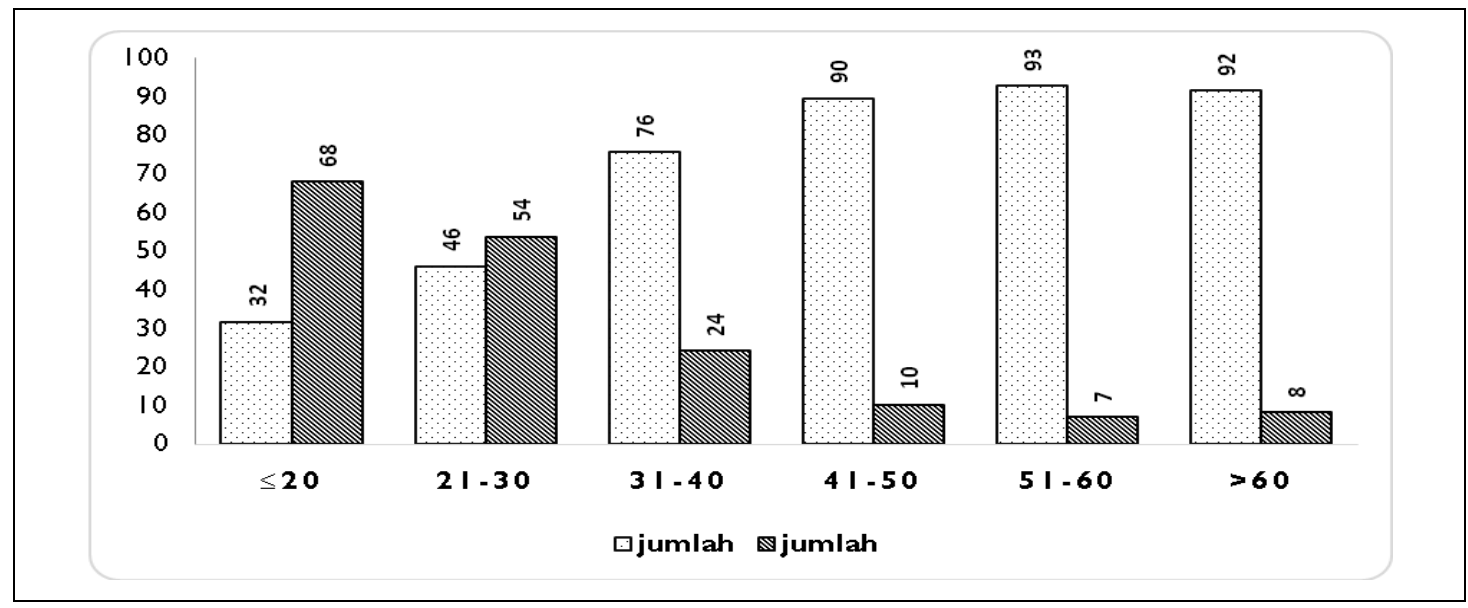

\section{Gambarl. Grafik Data responden berdasarkan karakteristik usia Figurel. Graph of respondent data based on age characteristics}

Berdasarkan Gambar I dapat diketahui bahwa responden terbanyak yang menggunakan tanaman obat berada pada kisaran usia 5I-60 tahun yaitu sebanyak 93\%, dan pengguna tanaman obat dengan jumlah paling sedikit berada pada kisaran usia $\leq 20$ tahun yaitu sebanyak $32 \%$. Berdasarkan hasil wawancara, pengetahuan tentang tanaman merupakan pengetahuan turun temurun yang diwariskan oleh generasi sebelumnya. Namun seiring dengan perkembangan bidang kesehatan, pengetahuan itu tidak diwariskan kepada generasi saat ini sehingga sangat sedikit responden yang berusia di bawah 20 tahun yang mengetahui dan menggunakan tanaman obat. Hal ini sejalan dengan pernyataan Voeks (2007) bahwa tingkat pengetahuan etnobotani masyarakat dengan umur tua lebih tinggi dibandingkan yang lebih muda. Selain itu, adanya perkembangan zaman yang lebih modern dan didukung oleh kemajuan teknologi, disertai gaya hidup yang serba instan dapat membuat minat generasi muda untuk mempelajari pengetahuan tentang obat tradisional semakin berkurang. 


\section{Tingkat pendidikan}

Responden terbanyak yang menggunakan tanaman obat pada penelitian ini adalah responden yang berpendidikan tidak tamat SD yaitu sebanyak $88 \%$, dan pengguna paling sedikit berpendidikan SMP yaitu sebanyak $41 \%$. Data responden berdasarkan tingkat pendidikan dapat dilihat pada Gambar 2.

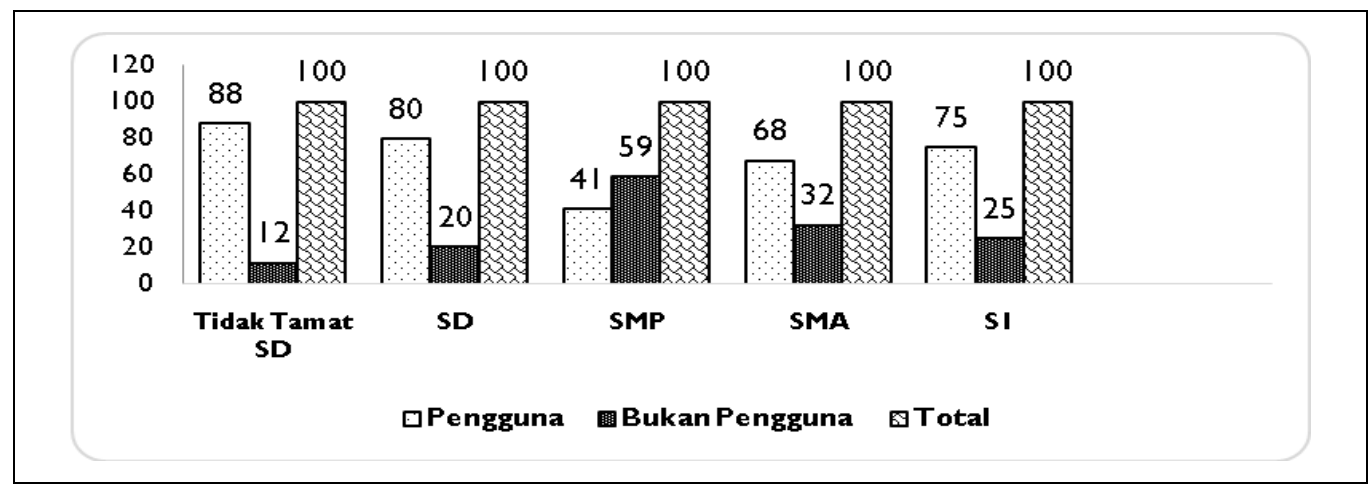

Gambar 2. Grafik data responden berdasarkan tingkat pendidikan Figure2 Graph of respondent data based on education level

Berdasarkan data pada Gambar 2 dapat diketahui bahwa masyarakat dengan tingkat pendidikan rendah (tidak tamat SD) memperoleh pengetahuan tentang tanaman obat secara turun temurun. Masyarakat tersebut lebih percaya terhadap tanaman obat karena telah terbiasa menggunakannya baik untuk tindakan preventif maupun penyembuhan penyakit. Hal ini sejalan dengan penelitian Puspaningrum (2010) yang mengatakan bahwa pendidikan tidak memiliki pengaruh terhadap perilaku mengobati. Hal ini disebabkan karena probabilitas masyarakat memilih obat tradisional tergantung pada tingkat pengetahuan dan pemahaman individu mengenai pengobatan tradisional yang biasanya telah diperoleh dari pengalaman yang diwariskan oleh orang tua dan kebiasaan masyarakatnya.

\section{Pekerjaan}

Pengguna tanaman obat terbanyak pada penelitian ini bermata pencaharian sebagai petani (84\%), sedangkan pengguna paling sedikit adalah pelajar (23\%). Data responden berdasarkan mata pencaharian dapat dilihat pada Gambar 3.

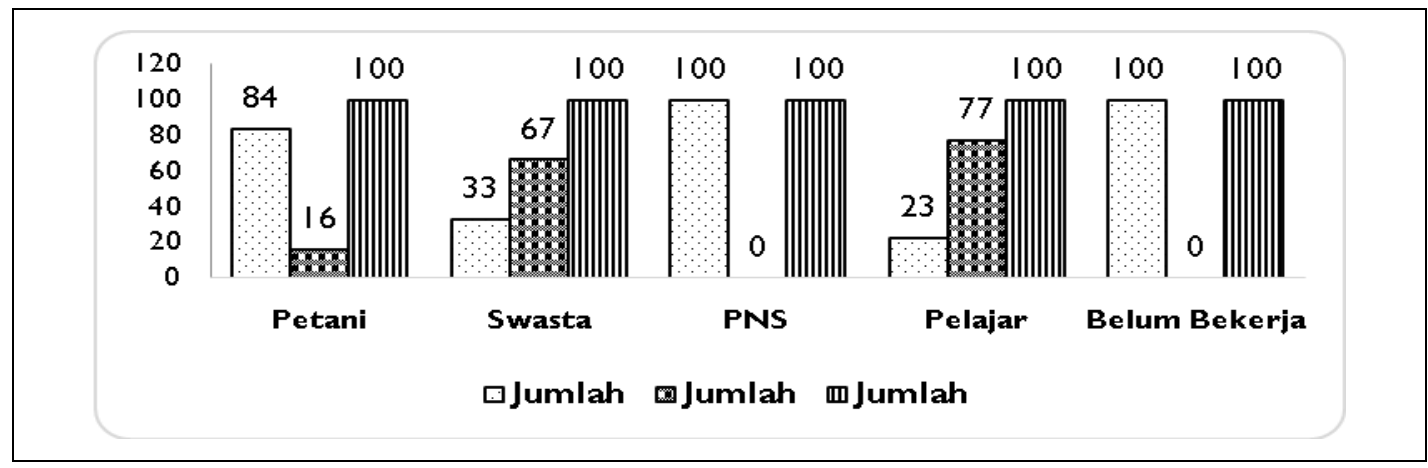

Gambar 3. Grafik data responden berdasarkan mata pencaharian Figure3. Graph of respondent data based on livelihood 
Berdasarkan Gambar 3, sebagian besar responden (78\%) bermata pencaharian sebagai petani, sehingga berpengaruh terhadap hasil penelitian. Namun pengguna tanaman obat paling sedikit pada penelitian ini adalah pelajar. Berdasarkan hasil wawancara, para pelajar yang berada di kisaran usia di bawah 20 tahun kurang memiliki pengetahuan tentang tanaman obat. $\mathrm{Hal}$ ini menunjukkan bahwa pengetahuan tentang tanaman obat yang dimiliki orang tua tidak diwariskan kepada anak-anaknya.

\section{Jenis kelamin}

Pengguna tanaman obat terbanyak pada penelitian ini adalah responden dengan jenis kelamin perempuan yaitu sebanyak $83 \%$. Hal ini menunjukkan bahwa kaum perempuan memiliki pengetahuan yang lebih banyak tentang tanaman obat dibandingkan dengan kaum lelaki. Data pengguna tanaman obat berdasarkan jenis kelamin dapat dilihat pada Gambar 4.

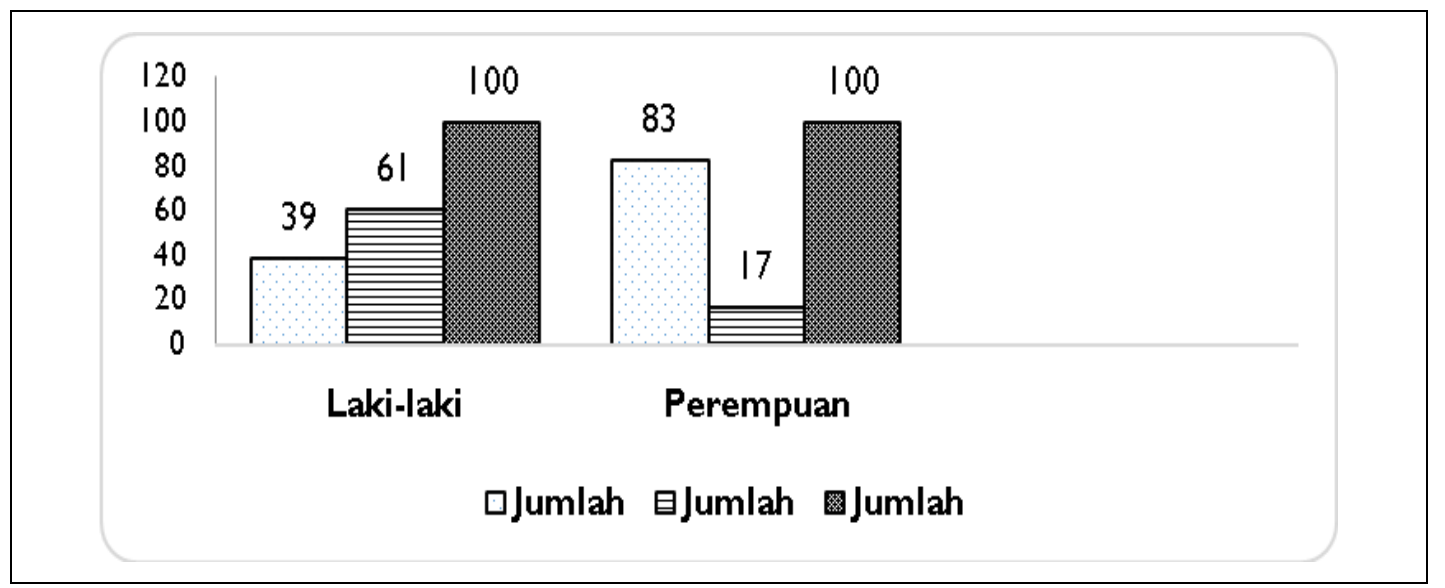

\section{Gambar 4. Grafik data responden berdasarkan jenis kelamin Figure 4. Graph of respondent data by gender}

\section{B. Jenis-Jenis Tanaman Obat Yang Digunakan Oleh Masyarakat Kecamatan Nangapanda}

Dari hasil penelitian ini telah teridentifikasi secara morfologi didapat sebanyak 54 spesies dari 30 famili tanaman lokal yang digunakan masyarakat Desa Ondorea Barat, Desa Timba Zi'a dan Desa Uzu Zozo sebagai obat tradisional Jenis-jenis tanaman obat yang dimanfaatkan oleh masyarakat Kecamatan Nangapanda, kabupaten Ende adalah sebagai berikut:

Tabel I. Jenis tanaman obat yang digunakan oleh masyarakat Kecamatan Nangapanda Kabupaten Ende Nusa Tenggara Timur

Table I. Types of medicinal plants used by the people of Nangapanda District, Ende Regency, East Nusa Tenggara

\begin{tabular}{lllll}
\hline No & $\begin{array}{c}\text { Umum/Lokal } \\
\text { (Common Namel } \\
\text { Local Name) }\end{array}$ & $\begin{array}{c}\text { Nama Latin/Famili } \\
\text { (Latin Name/Family) }\end{array}$ & Kegunaan (Utility) & $\begin{array}{c}\text { Bagian yang digunakan } \\
\text { (The Part Used) }\end{array}$ \\
\hline I. Jarak pagar/iza & $\begin{array}{l}\text { Jatrhopa curcas L./ } \\
\text { Euphorbiaceae }\end{array}$ & $\begin{array}{l}\text { Penurun panas, sakit gigi, sakit } \\
\text { telinga, sakit mata, sakit kepala, } \\
\text { bengkak }\end{array}$ & Daun dan getah \\
\hline
\end{tabular}




\begin{tabular}{|c|c|c|c|c|}
\hline No & $\begin{array}{c}\text { Nama } \\
\text { Umum/Lokal } \\
\text { (Common Namel } \\
\text { Local Name) }\end{array}$ & $\begin{array}{l}\text { Nama Latin/Famili } \\
\text { (Latin Name/Family) }\end{array}$ & Kegunaan (Utility) & $\begin{array}{c}\text { Bagian yang digunakan } \\
\text { (The Part Used) }\end{array}$ \\
\hline 2. & Pisang/Muku & $\begin{array}{l}\text { Musa paradisiacall } \\
\text { Musaceae }\end{array}$ & Penghilang Bengkak, pegal linu & Tunas, daun kering \\
\hline 3. & Mengkudu/ Kembo & $\begin{array}{l}\text { Morinda citrifolia L/ } \\
\text { Rubiaceae }\end{array}$ & Mengobati komplikasi & Daun, buah \\
\hline 4. & Pepaya/Uta ba’i & $\begin{array}{l}\text { Carica papaya L/ } \\
\text { Caricaceae }\end{array}$ & Obat cacing dan malaria & Daun \\
\hline 5. & Kunyit/kune & $\begin{array}{l}\text { Curcuma longa L/ } \\
\text { Zingiberaceae }\end{array}$ & Anti bakteri & Rimpang \\
\hline 6. & Kencur/seku & $\begin{array}{l}\text { Kaempferia galangall } \\
\text { Zingiberaceae }\end{array}$ & Demam, sakit perut & Rimpang \\
\hline 7. & Jahe/zea & $\begin{array}{l}\text { Zingiber officinale/ } \\
\text { Zingiberaceae }\end{array}$ & Luka luar dan sakit tenggorokan & Rimpang \\
\hline 8. & $\begin{array}{l}\text { Bawang merah/ } \\
\text { somu }\end{array}$ & $\begin{array}{l}\text { Allium cepal } \\
\text { Amaryllidaceae }\end{array}$ & Demam & Umbi \\
\hline 9. & $\begin{array}{l}\text { Bawang putih/ } \\
\text { sunga }\end{array}$ & $\begin{array}{l}\text { Allium } \\
\text { sativum/Alliaceae }\end{array}$ & Maag & Umbi \\
\hline 10. & Lengkuas/zaja & $\begin{array}{l}\text { Alpinia galangall } \\
\text { Zingiberaceae }\end{array}$ & Penyakit kulit & Umbi \\
\hline 11. & $\begin{array}{l}\text { Kunyit putih/ Kune } \\
\text { bhara }\end{array}$ & $\begin{array}{l}\text { Curcuma zedoarial } \\
\text { Zingiberaceae }\end{array}$ & Nyeri haid dan perut kembung & Rimpang \\
\hline 12. & $\begin{array}{l}\text { Jahe merah/Zea } \\
\text { toro }\end{array}$ & $\begin{array}{l}\text { Zingiber officinale/ } \\
\text { Zingiberaceae }\end{array}$ & Sakit kepala dan batuk & Rimpang \\
\hline 13. & $\begin{array}{l}\text { Kemangi kecil/ } \\
\text { Hate }\end{array}$ & $\begin{array}{l}\text { Ocimum citriodorum/ } \\
\text { Lamiaceae }\end{array}$ & Luka dalam & Daun \\
\hline 14. & Kesambi & $\begin{array}{l}\text { Schleichera oleosal } \\
\text { Sapindaceae }\end{array}$ & Bersihkan darah kotor & Kulit batang \\
\hline 15. & Kembang sepatu & $\begin{array}{l}\text { Hibiscus rosa-sinensis L.I } \\
\text { Malvaceae }\end{array}$ & Pertumbuhan rambut & daun \\
\hline 16. & Kumis kucing & $\begin{array}{l}\text { Orthosiphon spicatus } \\
\text { B.B.S/ Lamiaceae }\end{array}$ & Malaria & Daun \\
\hline 17. & $\begin{array}{l}\text { Sambiloto/ } \\
\text { sambaroto }\end{array}$ & $\begin{array}{l}\text { Andrographis paniculata } \\
\text { Ness/Acanthaceae }\end{array}$ & Malaria & Daun \\
\hline 18. & Hyptis/Ruba re’e & $\begin{array}{l}\text { Hyptis suaveolens/ } \\
\text { Lamiaceae }\end{array}$ & $\begin{array}{l}\text { Membersihkan darah kotor } \\
\text { pasca melahirkan }\end{array}$ & Daun \\
\hline 19. & Alang-alang/ Ki & $\begin{array}{l}\text { Imperata cylindricall } \\
\text { Poaceae }\end{array}$ & Obat ginjal, kencing batu & Akar \\
\hline 20. & $\begin{array}{l}\text { Jeruk purut/ } \\
\text { Mbangga }\end{array}$ & Citrus hystrix/ Rutaceae & Flu, penyakit kulit, bengkak & Daun dan buah \\
\hline 21. & $\begin{array}{l}\text { Sirih hutan/ Koro } \\
\text { wozo }\end{array}$ & $\begin{array}{l}\text { Piper Caducibracteum } \\
\text { C.DC/ Piperaceae }\end{array}$ & Bersihkan darah kotor & Daun dan biji \\
\hline 22. & $\begin{array}{l}\text { Daun ende/ Wunu } \\
\text { kada }\end{array}$ & $\begin{array}{l}\text { Centella } \\
\text { asiatica/Mackinlayacea }\end{array}$ & Demam & Daun \\
\hline 23. & Mimba/ Nimba & $\begin{array}{l}\text { Azadirachta indical } \\
\text { Meliaceae }\end{array}$ & Obat kulit & Daun \\
\hline 24. & Biduri / Kode & $\begin{array}{l}\text { Calotropis gigantean/ } \\
\text { Apocynaceae }\end{array}$ & Sakit gigi, ambeyen & Getah, Daun \\
\hline 25. & Tembakau/ Bako & $\begin{array}{l}\text { Nicotiana tabacum/ } \\
\text { Solanaceae }\end{array}$ & Sakit perut & Daun \\
\hline 26. & Sukun/Karara & $\begin{array}{l}\text { Artocarpus altilis/ } \\
\text { Moraceae }\end{array}$ & Asam urat, diabetes & Daun \\
\hline 27. & $\begin{array}{l}\text { Belimbing wuluh/ } \\
\text { Mbindi }\end{array}$ & $\begin{array}{l}\text { Averrhoa bilimbil } \\
\text { Oxalidaceae }\end{array}$ & Rematik, pegal linu & Daun \\
\hline
\end{tabular}




\begin{tabular}{|c|c|c|c|c|}
\hline No & $\begin{array}{c}\text { Nama } \\
\text { Umum/Lokal } \\
\text { (Common Namel } \\
\text { Local Name) }\end{array}$ & $\begin{array}{l}\text { Nama Latin/Famili } \\
\text { (Latin Name/Family) }\end{array}$ & Kegunaan (Utility) & $\begin{array}{c}\text { Bagian yang digunakan } \\
\text { (The Part Used) }\end{array}$ \\
\hline 28. & Labu putih / Boda & $\begin{array}{l}\text { Lagenaria sicerarial } \\
\text { Cucurbitaceae }\end{array}$ & $\begin{array}{l}\text { Penurun panas dan tekanan } \\
\text { darah tinggi }\end{array}$ & Buah \\
\hline 29. & Jambu/Guawa & $\begin{array}{l}\text { Psidium guajaval } \\
\text { Myrtaceae }\end{array}$ & Menceret & Daun \\
\hline 30. & Daun afrika & $\begin{array}{l}\text { Vernonia amygdalinal } \\
\text { Rosaceae }\end{array}$ & $\begin{array}{l}\text { Asam urat, kolestrol, darah } \\
\text { tinggi }\end{array}$ & Daun \\
\hline 31. & Waru & $\begin{array}{l}\text { Hibiscus tiliaceus/ } \\
\text { Malvaceae }\end{array}$ & Paru, paru, batuk amandel & Daun \\
\hline 32. & $\begin{array}{l}\text { Daun } \quad \text { sirsak/ } \\
\text { Srikaya }\end{array}$ & $\begin{array}{l}\text { Annona muricatal } \\
\text { Annonaceae }\end{array}$ & Lambung & Daun tua \\
\hline 33. & $\begin{array}{l}\text { Terung } \\
\text { Mberi lo'o }\end{array}$ & $\begin{array}{l}\text { Solanum torvum/ } \\
\text { Solanaceae }\end{array}$ & Sakit kepala & Buah \\
\hline 34. & Kaliraga & $\begin{array}{l}\text { Acorus calamus L./ } \\
\text { Araceae }\end{array}$ & Sakit perut & Daun \\
\hline 35. & $\begin{array}{l}\text { Daun kentut/ } \\
\text { Fange }\end{array}$ & $\begin{array}{l}\text { Paederia foetidal } \\
\text { Rubiaceae }\end{array}$ & Pilek & daun \\
\hline 36. & Kemiri/ Feo & $\begin{array}{l}\text { Aleurites moluccanus/ } \\
\text { Euphorbiaceae }\end{array}$ & Batuk & $\mathrm{Biji}$ \\
\hline 37. & Gulma babadotan & $\begin{array}{l}\text { Ageratum conyzoides L.I } \\
\text { Asteraceae }\end{array}$ & Asam urat dan diabetes & Luka luar \\
\hline 38. & Pinang/ Eu & $\begin{array}{l}\text { Areca } \\
\text { catechu/Arecaceae }\end{array}$ & $\begin{array}{l}\text { Mimisan, menceret, sakit } \\
\text { pinggang }\end{array}$ & Buah \\
\hline 39. & Sirih/ Mengi & $\begin{array}{l}\text { Piper betle L./ } \\
\text { Piperaceae }\end{array}$ & Bersihkan darah kotor & Daun \\
\hline 40. & Binahong & $\begin{array}{l}\text { Anredera cordifolial } \\
\text { Basellaceae }\end{array}$ & Komplikasi & Daun \\
\hline 41. & Cabe/ Koro & $\begin{array}{l}\text { Capsicum frutescens/ } \\
\text { Solanaceae }\end{array}$ & Sakit mata & Daun \\
\hline 42. & $\begin{array}{l}\text { Temulawak/ Zea } \\
\text { jawa }\end{array}$ & $\begin{array}{l}\text { Curcuma zanthorrhizal } \\
\text { Zingiberaceae }\end{array}$ & $\begin{array}{l}\text { Menghilangkan radang dan } \\
\text { jerawat }\end{array}$ & Rimpang \\
\hline 43. & Daun kecubung & $\begin{array}{l}\text { Datura metel } \\
\text { Solanaceae }\end{array}$ & Obat bisul & Daun \\
\hline 44. & $\begin{array}{l}\text { Terung hutan/ } \\
\text { Mberi }\end{array}$ & $\begin{array}{l}\text { Solanum torvum/ } \\
\text { Solanaceae }\end{array}$ & Sakit jantung & Buah \\
\hline 45. & Reo /Kesi & $\begin{array}{l}\text { Lannea coromandelical } \\
\text { Anacardiaceae }\end{array}$ & Sakit gigi dan luka & Getah \\
\hline 46. & Lidah buaya & $\begin{array}{l}\text { Aloe veral } \\
\text { Xanthorrhoeaceae }\end{array}$ & $\begin{array}{l}\text { Pertumbuhan rambut } \\
\text { membersihkan wajah }\end{array}$ & daun \\
\hline 47. & Mahoni & $\begin{array}{l}\text { Swietenia mahagonil } \\
\text { Meliaceae }\end{array}$ & Gatal-gatal & Daun \\
\hline 48. & Beluntas & $\begin{array}{l}\text { Pluchea indica (L.)/ } \\
\text { Asteraceae }\end{array}$ & Bau badan, pencernaan & Semua bagian \\
\hline 49. & Mbari & & Gusi bengkak & Daun \\
\hline
\end{tabular}




\begin{tabular}{|c|c|c|c|c|}
\hline No & $\begin{array}{c}\text { Nama } \\
\text { Umum/Lokal } \\
\text { (Common Namel } \\
\text { Local Name) }\end{array}$ & $\begin{array}{l}\text { Nama Latin/Famili } \\
\text { (Latin Name/Family) }\end{array}$ & Kegunaan (Utility) & $\begin{array}{c}\text { Bagian yang digunakan } \\
\text { (The Part Used) }\end{array}$ \\
\hline 50. & $\mathrm{~Pa}$ & & Lambung & Daun \\
\hline 51. & & & Perut buncit & Pucuk \\
\hline 52. & Puzu & & Luka & \\
\hline 53. & Heba/simbo & & Liver & Daun \\
\hline 54. & Kaju/kombe & & $\begin{array}{l}\text { Mandi anak yang sering } \\
\text { sakit-sakitan }\end{array}$ & Daun \\
\hline
\end{tabular}

\section{Nilai Guna Jenis Tanaman Obat}

Nilai guna jenis tanaman obat menggambarkan tingkat nilai guna spesies tanaman dalam mengobati suatu kategori penyakit berdasarkan kategori penyakit. Nilai guna jenis tanaman obat untuk semua jenis tanaman yang diperoleh pada penelitian ini dapat dilihat pada Tabel 2.

Terdapat 6 jenis tanaman lokal yang biasa dimanfaatkan sebagai obat oleh masyarakat di lokasi penelitian dan belum diketahui nama latinnya, jenis tanaman tersebut yaitu Mbari, Pa, Pira, Puzu, Heba/simbo dan Kaju/kombe. Jenis-jenis tersebut biasanya dimanfaatkan masyarakat di Desa Ondorea Barat, Desa Timba Zi'a dan Desa Uzu Zozo untuk mengobati Gusi bengkak, Lambung, Perut buncit dan Luka. Oleh karena itu ke depan perlu dilakukan identifikasi atau determinasi jenis tanaman tersebut. Agar namanya benar dan tempatnya tepat dalam sistem klasifikasi. Sehingga identitasnya diketahui secara detail dan lengkap serta dapat dipertanggungjawabkan secara ilmiah. 
Tabel 2. Nilai guna jenis tanaman obat Table 2. Use value of medicinal plants

\begin{tabular}{|c|c|c|c|c|}
\hline No & $\begin{array}{c}\text { Nama } \\
\text { Umum/Lokal } \\
\text { (Common namel } \\
\text { local name) }\end{array}$ & $\begin{array}{l}\text { Nama Latin/Family } \\
\text { (latin namelfamily) }\end{array}$ & Kegunaan (Utility) & $\begin{array}{l}\text { Use Value } \\
\left(U V_{s}\right)\end{array}$ \\
\hline $\mathrm{I}$. & Jarak pagar/iza & $\begin{array}{l}\text { Jatrhopa curcas L./ } \\
\text { Euphorbiaceae }\end{array}$ & $\begin{array}{l}\text { Penurun panas, sakit gigi, sakit telinga, } \\
\text { sakit mata, sakit kepala, bengkak }\end{array}$ & 3,76 \\
\hline 2. & Pisang/Muku & $\begin{array}{l}\text { Musa } \\
\text { Musaceae }\end{array}$ & Penghilang Bengkak, pegal linu & 2,96 \\
\hline 3. & Mengkudu/ Kembo & $\begin{array}{l}\text { Morinda citrifolia L/ } \\
\text { Rubiaceae }\end{array}$ & Mengobati komplikasi & 3,11 \\
\hline 4. & Pepaya/Uta ba’i & $\begin{array}{l}\text { Carica papaya L/ } \\
\text { Caricaceae }\end{array}$ & Obat cacing dan malaria & 2,59 \\
\hline 5. & Kunyit/kune & $\begin{array}{l}\text { Curcuma longa L/ } \\
\text { Zingiberaceae }\end{array}$ & Anti bakteri & 3,33 \\
\hline 6. & Kencur/seku & $\begin{array}{l}\text { Kaempferia galangall } \\
\text { Zingiberaceae }\end{array}$ & Demam, sakit perut & 3,26 \\
\hline 7. & Jahe/zea & $\begin{array}{l}\text { Zingiber } \\
\text { Zingiberaceae }\end{array}$ & Luka luar dan sakit tenggorokan & 3,19 \\
\hline 8. & $\begin{array}{l}\text { Bawang merah/ } \\
\text { somu }\end{array}$ & $\begin{array}{l}\text { Allium } \\
\text { Amaryllidaceae }\end{array}$ & Demam & 3,26 \\
\hline 9. & Bawang putih/ sunga & Allium sativum/Alliaceae & Maag & 3,33 \\
\hline 10. & Lengkuas/zaja & $\begin{array}{ll}\text { Alpinia } & \text { galangall } \\
\text { Zingiberaceae } & \end{array}$ & Penyakit kulit & 2,22 \\
\hline II. & $\begin{array}{l}\text { Kunyit putih/ Kune } \\
\text { bhara }\end{array}$ & $\begin{array}{l}\text { Curcuma } \\
\text { Zingiberaceae }\end{array}$ & Nyeri haid dan perut kembung & 2,96 \\
\hline 12. & Jahe merah/Zea toro & $\begin{array}{l}\text { Zingiber } \\
\text { Zingiberaceae }\end{array}$ & Sakit kepala dan batuk & 2,15 \\
\hline 13. & Kemangi kecil/ Hate & $\begin{array}{l}\text { Ocimum } \\
\text { Lamiaceae }\end{array}$ & Luka dalam & $\mathrm{I}, 48$ \\
\hline 14. & Kesambi & $\begin{array}{l}\text { Schleichera oleosal } \\
\text { Sapindaceae }\end{array}$ & Bersihkan darah kotor & 0,81 \\
\hline 15. & Kembang sepatu & $\begin{array}{l}\text { Hibiscus rosa-sinensis L./ } \\
\text { Malvaceae }\end{array}$ & Pertumbuhan rambut & 2,22 \\
\hline 16. & Kumis kucing & $\begin{array}{l}\text { Orthosiphon spicatus B.B.S/ } \\
\text { Lamiaceae }\end{array}$ & Malaria & 3,04 \\
\hline 17. & $\begin{array}{l}\text { Sambiloto/ } \\
\text { sambaroto }\end{array}$ & $\begin{array}{l}\text { Andrographis paniculata } \\
\text { Ness/Acanthaceae }\end{array}$ & Malaria & 3,26 \\
\hline 18. & Hyptis/Ruba re'e & $\begin{array}{l}\text { Hyptis } \quad \text { suaveolens/ } \\
\text { Lamiaceae }\end{array}$ & $\begin{array}{l}\text { Membersihkan darah kotor pasca } \\
\text { melahirkan }\end{array}$ & 3,11 \\
\hline 19. & Alang-alang/ Ki & $\begin{array}{l}\text { Imperata } \quad \text { cylindricall } \\
\text { Poaceae }\end{array}$ & Obat ginjal, kencing batu & 1,63 \\
\hline 20. & $\begin{array}{l}\text { Jeruk } \\
\text { Mbangga }\end{array}$ & Citrus hystrix/ Rutaceae & Flu, penyakit kulit, bengkak & 1,85 \\
\hline 21. & $\begin{array}{l}\text { Sirih hutan/ Koro } \\
\text { wozo }\end{array}$ & $\begin{array}{l}\text { Piper Caducibracteum C.DCI } \\
\text { Piperaceae }\end{array}$ & Bersihkan darah kotor & 3,19 \\
\hline 22. & $\begin{array}{l}\text { Daun ende/ Wunu } \\
\text { kada }\end{array}$ & $\begin{array}{l}\text { Centella } \\
\text { asiatica/Mackinlayacea }\end{array}$ & Demam & 3,26 \\
\hline 23. & Mimba/ Nimba & $\begin{array}{l}\text { Azadirachta indical } \\
\text { Meliaceae }\end{array}$ & Obat kulit & 2,22 \\
\hline 24. & Biduri / Kode & $\begin{array}{l}\text { Calotropis } \\
\text { Apocynaceae }\end{array}$ & Sakit gigi, ambeyen & 2,59 \\
\hline 25. & Tembakau/ Bako & $\begin{array}{l}\text { Nicotiana } \\
\text { Solanaceae }\end{array}$ & Sakit perut & 2,37 \\
\hline
\end{tabular}




\begin{tabular}{|c|c|c|c|c|}
\hline No & $\begin{array}{c}\text { Nama } \\
\text { Umum/Lokal } \\
\text { (Common namel } \\
\text { local name) }\end{array}$ & $\begin{array}{l}\text { Nama Latin/Family } \\
\text { (latin name/family) }\end{array}$ & Kegunaan (Utility) & $\begin{array}{l}\text { Use Value } \\
\left.\text { (UV } V_{s}\right)\end{array}$ \\
\hline 26. & Sukun/Karara & Artocarpus altilis/ Moraceae & Asam urat, diabetes & 2,44 \\
\hline 27. & $\begin{array}{l}\text { Belimbing wuluh/ } \\
\text { Mbindi }\end{array}$ & $\begin{array}{l}\text { Averrhoa } \quad \text { bilimbil } \\
\text { Oxalidaceae }\end{array}$ & Rematik, pegal linu & 2,15 \\
\hline 28. & Labu putih / Boda & $\begin{array}{ll}\text { Lagenaria } & \text { sicerarial } \\
\text { Cucurbitaceae } & \end{array}$ & $\begin{array}{l}\text { Penurun panas dan tekanan darah } \\
\text { tinggi }\end{array}$ & 1,85 \\
\hline 29. & Jambu/Guawa & Psidium guajava/ Myrtaceae & Menceret & 1,63 \\
\hline 30. & Daun afrika & $\begin{array}{l}\text { Vernonia amygdalinal } \\
\text { Rosaceae }\end{array}$ & Asam urat, kolestrol, darah tinggi & 3,48 \\
\hline 31. & Waru & $\begin{array}{l}\text { Hibiscus } \\
\text { Malvaceae }\end{array}$ & Paru, paru, batuk amandel & 2,22 \\
\hline 32. & Daun sirsak/ Srikaya & $\begin{array}{l}\text { Annona } \\
\text { Annonaceae }\end{array}$ & Lambung & 2,07 \\
\hline 33. & $\begin{array}{l}\text { Terung kecil/ Mberi } \\
\text { lo'o }\end{array}$ & $\begin{array}{l}\text { Solanum } \\
\text { Solanaceae }\end{array}$ & Sakit kepala & $\mathrm{I}, 63$ \\
\hline 34. & Kaliraga & Acorus calamus L./ Araceae & Sakit perut & 3,78 \\
\hline 35. & Daun kentut/ Fange & Paederia foetida/ Rubiaceae & Pilek & 2,67 \\
\hline 36. & Kemiri/ Feo & $\begin{array}{l}\text { Aleurites moluccanus/ } \\
\text { Euphorbiaceae }\end{array}$ & Batuk & 3,04 \\
\hline 37. & Gulma babadotan & $\begin{array}{l}\text { Ageratum conyzoides L.I } \\
\text { Asteraceae }\end{array}$ & Asam urat dan diabetes & 2,89 \\
\hline 38. & Pinang/ Eu & Areca catechu/Arecaceae & Mimisan, menceret, sakit pinggang & 2,37 \\
\hline 39. & Sirih/ Mengi & Piper betle L./ Piperaceae & Bersihkan darah kotor & 3,78 \\
\hline 40. & Binahong & $\begin{array}{ll}\text { Anredera } & \text { cordifolial } \\
\text { Basellaceae } & \end{array}$ & Komplikasi & 3,85 \\
\hline $4 \mathrm{I}$. & Cabe/ Koro & $\begin{array}{l}\text { Capsicum frutescens/ } \\
\text { Solanaceae }\end{array}$ & Sakit mata & 2,00 \\
\hline 42. & $\begin{array}{l}\text { Temulawak/ Zea } \\
\text { jawa }\end{array}$ & $\begin{array}{l}\text { Curcuma zanthorrhizal } \\
\text { Zingiberaceae }\end{array}$ & Menghilangkan radang dan jerawat & 3,78 \\
\hline 43. & Daun kecubung & Datura metel Solanaceae & Obat bisul & 3,04 \\
\hline 44. & Terung hutan/ Mberi & $\begin{array}{ll}\text { Solanum } & \text { torvum/ } \\
\text { Solanaceae } & \end{array}$ & Sakit jantung & 2,07 \\
\hline 45. & Reo /Kesi & $\begin{array}{l}\text { Lannea coromandelical } \\
\text { Anacardiaceae }\end{array}$ & Sakit gigi dan luka & $\mathrm{I}, 85$ \\
\hline 46. & Lidah buaya & $\begin{array}{ll}\text { Aloe } & \text { veral } \\
\text { Xanthorrhoeaceae } & \end{array}$ & $\begin{array}{l}\text { Pertumbuhan rambut } \\
\text { membersihkan wajah }\end{array}$ & 1,48 \\
\hline 47. & Mahoni & $\begin{array}{l}\text { Swietenia mahagonil } \\
\text { Meliaceae }\end{array}$ & Gatal-gatal & 1,33 \\
\hline 48. & Beluntas & $\begin{array}{l}\begin{array}{l}\text { Pluchea indica (L.)/ } \\
\text { Asteraceae }\end{array} \\
\end{array}$ & Bau badan, pencernaan & 2,07 \\
\hline 49. & Mbari & & Gusi bengkak & 0,13 \\
\hline 50. & $\mathrm{~Pa}$ & & Lambung & 0,10 \\
\hline 51. & Pira & & Perut buncit & 0,10 \\
\hline 52. & Puzu & & Luka & 0,09 \\
\hline 53. & Heba/simbo & & Liver & 0,08 \\
\hline 54. & Kaju/kombe & & Mandi anak yang sering sakit-sakitan & 0,13 \\
\hline
\end{tabular}


Berdasarkan dari hasil analisa data diketahui bahwa nilai guna jenis tanaman obat tertinggi terdapat pada tanaman jarak pagar dengan nilai $U v_{\text {is }}$ sebesar 3,76 atau masuk dalam kategori tumbuhan yang penting atau spesies prioritas $\left(3 \leq U V_{s} \leq 6\right)$, sedangkan nilai guna jenis tanaman obat terendah terdapat pada tanaman heba/simbo dengan nilai $U \mathrm{Vi}_{\mathrm{s}}$ sebesar 0,08 atau masuk dalam kategori bukan spesies prioritas. Tanaman damar masuk dalam kategori prioritas karena hampir semua bagian tanaman digunakan oleh sebagian besar masyarakat.

Tanaman jarak pagar biasa digunakan masyarakat untuk mengobati demam atau panas tinggi pada anak, bengkak, sakit mata, sakit telinga, sakit gigi dan sakit kepala. Untuk mengobati demam pada anak, daun damar dicampur dengan kencur, ditumbuk lalu ditempelkan pada ubun-ubun anak. Untuk sakit mata dan sakit kepala, daun jarak pagar dihangatkan lalu ditempelkan pada bagian yang sakit. Sementara itu, untuk sakit kepala, daun jarak pagar direndam dengan air dingin lalu dikompreskan pada kepala. Menurut (Prasad, Izam \& Khan (2012) Jarak pagar Jatropha curcas) merupakan tanaman yang memiliki banyak manfaat untuk kesehatan dan mengandung zat aktif berupa flavonoid, saponin, tannin, alkaloid dan protease cucain. Flavonoid memiliki sifat anti bakteri dan antioksidan yang dapat mengahambat bakteri patogen, sehingga infeksi luka dapat diminimalisir bahkan tidak terjadi.

Masyarakat kecamatan Nangapanda menggunakan semua bagian tanaman dari akar hingga daun kerena meyakini setiap bagian memiliki khasiatnya masing-masing. Bagian tanaman yang paling banyak digunakan adalah daun. Dengan jumlah daun yang banyak, masyarakat dapat mengambilnya tanpa merusak organ lainnya sehingga tumbuhan masih dapat tumbuh dan berkembang. Hal ini sejalan dengan penelitian yang dilakukan oleh Karmilasanti dan Supartini (20II) yang mengatakan bahwa masyarakat biasanya memandang bagian daun sebagai bagian yang paling banyak mengandung obat yang dibutuhkan oleh masyarakat.

\section{Pengetahuan Masyarakat Kecamatan Nangapanda tentang tanaman Obat}

Berdasarkan data angket yang diberikan, diketahui dari 135 responden terdapat 99 responden $(73 \%)$ yang memanfaatkan tanaman obat untuk kegiatan preventif maupun penyembuhan penyakit. Tanaman obat yang digunakan umumnya tidak dibudidayakan tetapi tumbuh sebagai tanaman liar di hutan dan daerah sekitar pemukiman penduduk. Penelitian ini dilakukan di tiga desa di kecamatan Nangapanda yaitu Desa Ondorea Barat, Timba Zi'a dan Uzu Zozo. Dari ketiga desa tersebut, pengguna terbanyak terdapat pada Desa Ondorea Barat yaitu sebanyak 63 responden, disusul oleh desa Timba Zi'a sebanyak 42 responden dan desa Uzu zozo sebanyak 30 responden.

Masyarakat Desa Ondorea Barat telah menggunakan tanaman obat sejak lama. Pengetahuan tentang pemanfaatan dan cara pembuatan tanaman obat tersebut diketahui dari leluhur atau orang tua yang diwariskan secara turun temurun. Masyarakat Desa Ondorea barat biasanya menggunakan tanaman obat untuk kegiatan penyembuhan penyakit dengan cara direbus lalu diminum, ditempel di bagian yang sakit, maupun dimakan langsung.

Berdasarkan hasil wawancara, masyarakat Desa Ondorea Barat sering menggunakan tanaman obat karena meyakini khasiat tanaman obat dapat menyembuhkan penyakit, mudah didapat dan tidak membutuhkan biaya untuk mendapatkannya. Hal ini sejalan dengan pernyataan Gitawati \& Handayani (2007) bahwa 
sebagian masyarakat yang menggunakan obat tradisional menganggap bahwa obat tradisional aman, bahkan lebih aman dibandingkan obatobatan kimia, serta lebih murah harganya.

\section{E. Jenis-jenis tanaman obat yang digunakan oleh masyarakat kecamatan Nangapanda}

Berdasarkan hasil wawancara terhadap I35 responden dan tracking yang dilakukan terhadap tiga titik yang terdapat pada ketiga desa diperoleh 54 jenis tanaman yang berasal dari 30 famili yang umumnya digunakan oleh masyarakat, seperti yang tersaji pada Tabel I.

Berdasarkan Tabel I di atas terdapat beberapa jenis tanaman yang tidak dituliskan nama umum dan nama ilmiahnya, namun hanya diberikan nama lokal dan gambarnya karena peneliti belum melakukan identifikasi untuk mengetahui nama ilmiah tanaman-tanaman tersebut dan tanaman tersebut hanya diketahui dan dimanfaatkan oleh sedikit responden. Hal ini terlihat dari nilai $U V_{s}$ yang sangat kecil untuk keenam jenis tanaman yang belum teridentifikasi tersebut. Berdasarkan hasil tracking yang dilakukan, tanaman-tanaman tersebut tersebar pada tiga titik. Titik pertama di Desa Ondorea Barat, titik kedua Desa Timba Zi'a dan titik ketiga desa Uzu Zozo.

\section{Titik Pertama}

Titik pertama menunjukkan sebaran tanaman obat yang terdapat di desa Ondorea Barat, seperti yang tertera pada Gambar 5 berikut.

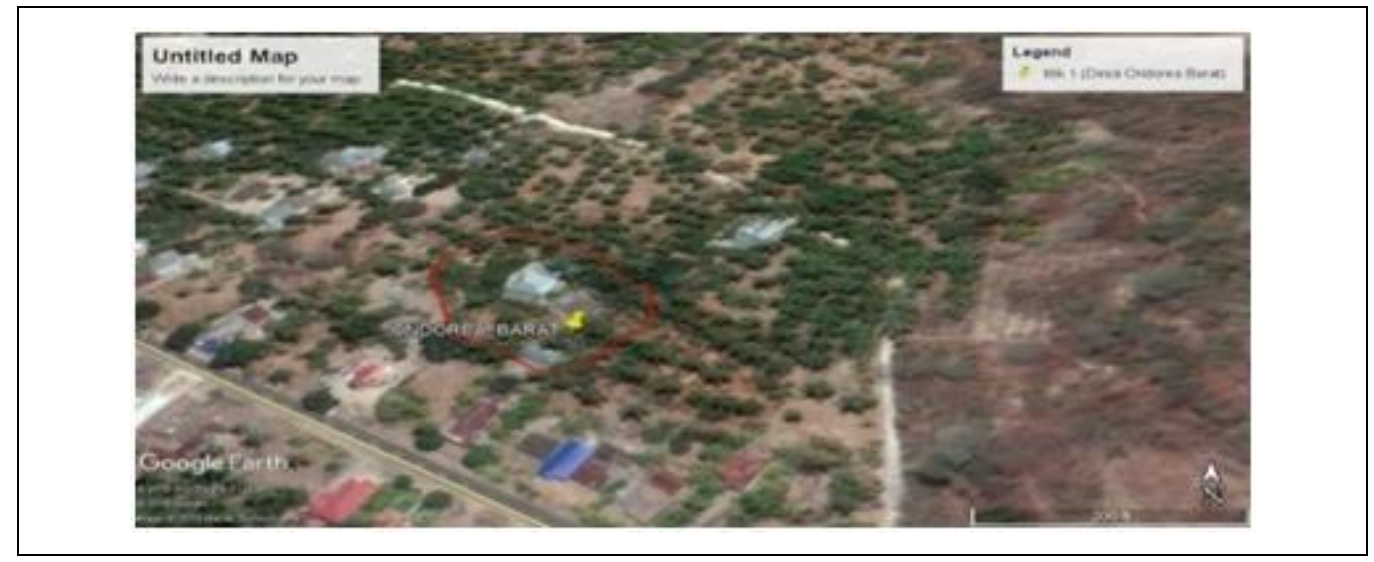

\section{Gambar 5. Sebaran tanaman obat di Desa Ondorea Barat Figure 5. Distribution of medicinal plants in the village of West Ondorea}

Tanaman tersebar di sekitar pemukiman warga yang ditandai dengan garis merah. Tanaman-tanaman yang ditemukan di wilayah tersebut sebanyak 50 jenis yaitu, Jarak pagar, pisang, mengkudu, pepaya, kunyit, kencur, jahe, bawang merah, bawang putih, lengkuas, kunyit putih, kemangi kecil,kesambi, kumis kucing, sambiloto, Hyptis, sirih hutan, daun ende, mimba, tembakau, suku, belimbing wuluh, labu putih, jambu, daun afrika, waru, daun sirsak, terung kecil, kaliraga daun kentut, kemiri, babadotaan, pinang, sirih, binahong, cabe, temulawak, daun kecubung, terung hutan, reo, lidah buaya, mahoni, beluntas, mbari, pa, pira, puzu, heba, dan kaju kombe.

2. Titik kedua

Sebaran tanaman obat di Desa Timba Zi'a dapat dilihat pada Gambar 6 berikut. 


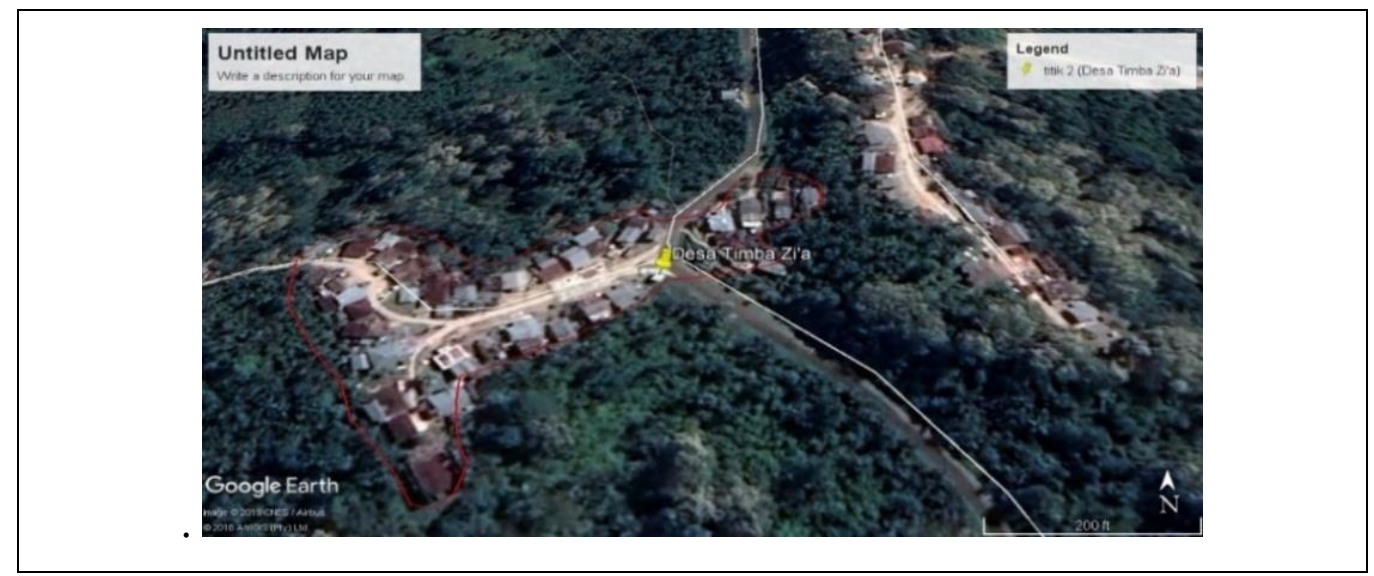

Gambar 6. Sebaran tanaman obat di Desa Timba Zi’a Figure 6. Distribution of medicinal plants in Timba Zi'a Village

Tanaman-tanaman yang tersebar di Desa Timba Zi'a antara lain Jarak pagar, pisang, mengkudu, pepaya, kunyit, kencur, jahe, bawang merah, bawang putih, lengkuas, kunyit putih, kemangi kecil,kesambi, kumis kucing, sambiloto, kembang sepatu, sirih hutan, daun ende, mimba, tembakau, suku, jeruk purut, labu putih, jambu, biduri daun afrika, alang-alang, daun sirsak, terung kecil, kaliraga daun kentut, kemiri, babadotaan, pinang, sirih, binahong, cabe, temulawak, daun kecubung, terung hutan, reo, lidah buaya, mahoni, beluntas,

3. Titik ketiga

Sebaran tanaman obat di Desa Uzu Zozo seperti pada Gambar 7 berikut.

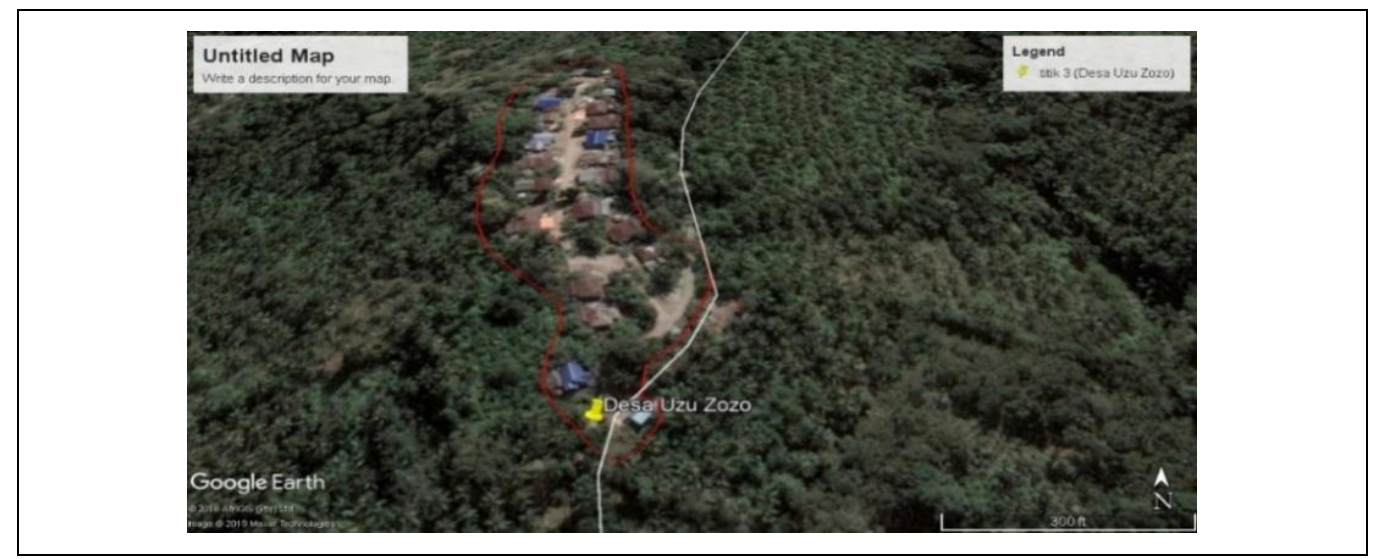

Gambar 7. Sebaran tanaman obat di Desa Uzu Zozo Figure 7. Distribution of medicinal plants in Uzu Zozo Village

Tanaman-tanaman yang tersebar di Desa Uzu Zozo antara lain jarak pagar, pisang, mengkudu, pepaya, kunyit, kencur, jahe, bawang merah, bawang putih, lengkuas, kunyit putih, kemangi kecil, kesambi, kumis kucing, sambiloto, Hyptis, sirih hutan, daun ende, mimba, tembakau, suku, belimbing wuluh, labu putih, jambu, daun afrika, waru, daun sirsak, terung kecil, kaliraga daun kentut, kemiri, babadotaan, pinang, sirih, binahong, cabe, temulawak, daun kecubung, terung hutan, reo, lidah buaya, mahoni, dan beluntas. 


\section{KESIMPULAN DAN SARAN}

\section{A. Kesimpulan}

Berdasarkan hasil penelitian dapat disimpulkan bahwa terdapat 73\% (99 responden) masyarakat di Kecamatan Nangapanda yang menggunakan tanaman obat untuk kegiatan preventif maupun penyembuhan penyakit serta terdapat 54 jenis tanaman obat yang berasal dari 30 famili yang umumnya digunakan.

\section{B. Saran}

Perlu dilakukan penelitian lanjutan untuk mengetahui bahan aktif yang terkandung dalam tanaman-tanaman obat di atas.

\section{DAFTAR PUSTAKA}

Darsini, N. N. 2013. "Analisis Keanekaragaman Jenis Tumbuhan Obat Tradisional Berkasiat Untuk Pengobatan Penyakit Saluran Kencing Di Kecamatan Kintamani, Kabupaten Bangli Provinsi Bali.”Jurnal Bumi Lestari I3(I): I59-65.

Gitawati, Retno and Rini Sasanti Handayani. 2007. "Akan Adanya Efek Samping Obat Tradisional." Buletin Penelitian Sistem Kesehatan II (3):284-85.

Karmilasanti, Karmilasanti and Supartini Supartini. 2011. "Keanekaragaman Jenis Tumbuhan Obat Dan Pemanfaatannya Di Kawasan Tane' Olen Desa Setulang Malinau, Kalimantan Timur." Jurnal Penelitian Dipterokarpa 5(1):23-38.

Nofiani, Risa. 2008. “Artikel Ulas Balik Urgensi Dan Mekanisme Biosintesis Metabolit Sekunder Mikroba Laut." Jurnal Natur Indonesia Nofiani Jurnal Natur Indonesia I0(102): I20-25.

Prasad, D. M. Reddy, Amirah Izam, and
Maksudur Rahman Khan. 2012. "Jatropha Curcas: Plant of Medical Benefits." 6(14):269|-99.

Puspaningrum, A. 20I0. "FAKTOR-FAKTOR YANG BERHUBUNGAN DENGAN Lembar Pengesahan Laporan Akhir Hasil Penelitian.” I-I7.

Santosa, Slamet. 20I5. "Khasiat Antioksidan Dan Antihipertensi Buah Mengkudu ( Morinda Citrifolia Fructus ) Dalam Penanganan Preeklamsi.” Jkm.

Sari, Cici Yuliana. 20I5. "Penggunaan Buah Mengkudu (Morinda Citrifolia L.) Untuk Menurunkan Tekanan Darah Tinggi." J Majority 4(3):34-40.

Sari, L. O. R. .. 2006. "Pemanfaatan Obat Tradisional Dan Keamanannya." Majalah IImu Kefarmasian III(I): I-7.

Suryanto, Rusli and Setiawan Djoni. 2013. "Struktur Data Datawarehouse Tanaman Obat Indonesia Dan Hasil Penelitian Obat Tradisional." Seminar Nasional Sistem Informasi Indonesia 2-4.

Voeks, Robert A. 2007. "Are Women Reservoirs of Traditional Plant Knowledge? Gender, Ethnobotany and Globalization in Northeast Brazil." Singapore Journal of Tropical Geography 28(I):7-20.

Wang, Mian Ying, Brett J. West, C. Jarakae Jensen, Diane Nowicki, Chen Su, Afa K. Palu, and Gary Anderson. 2002. "Morinda Citrifolia (Noni): A Literature Review and Recent Advances in Noni Research." Acta Pharmacologica Sinica 23(I2): I| $|27-4|$.

Wibowo, F. .. Sulistiyanto and PrasetyaningrumErna. 2015. : “: Pemanfaatan Ekstrak Batang Tanaman Pisang (Musa Paradisiacal) Sebagai Obat Antiacne Dalam Sediaan Gel Antiacne." Publikasi Fakultas Farmasi, 12(I):38-46. 
Jurnal FALOAK Vol. 4 No.I April 2020: 23-38 